engineering, although there is concern that the changes should not go too far for fear of conflict with work already being carried out by the National Institutes of Health.

There is widespread support for a proposed amendment that would require the National Bureau of Standards to engage in international cooperation, and that it should maintain measurement research and development as its top priority. The bureau's director, Dr Ernest Ambler, welcomed the committee's recommendation that any new new functions should be provided with adequate funds and manpower.

The committee's suggestion that the bureau be given authority to promote economic growth by "contributing to the development of the basic technologies which underlie product and process development, technological innovation and productivity' raises greater difficulties. Although the bureau does at present support research aimed at the general enhancement of industrial innovation - for example in computers or machine tools - these are undertaken only when they can be shown to be measurement-related. Members of the committee argue, however, that in practice

\section{Support for Argentinian}

\section{Leblon, Brazil}

Professor Nicolas G. Bazan, sacked in controversial circumstances as director of the Biochemical Research Institute of the University of the South in Bahia Blanca, Argentina (Nature 14 May, p.100), was greeted enthusiastically at a symposium last month organized by the Argentinian Academy of Sciences in the city of Córdoba.

Several of the foreign biologists invited to the symposium, on molecular aspects of the nervous system and memory, carried letters from their professional societies protesting against the dismissal of Bazan and the continued arbitrary attacks by the Argentinian government on scientists. Among them were letters from the American Society of Neurochemistry and from the European Society of Neurochemistry. In spite of the risks of reprisals, the Argentinian academy publicly endorsed these protests from the international scientific community.

Bazan has been invited to visit the United Kingdom to attend the forthcoming biannual meeting of the International Society for Neurochemistry in Nottingham next September, where a special symposium on the human rights issue in Latin America is being planned. It will deal in particular with the situation of the several hundred Argentinian scientists who are reported as "disappeared", "arrested" or "summarily dismissed".

Maurice Bazin the bureau already seems to be stretching its definition of measurement in some of the research that it supports. If the organization feels it is limited by the terms of its existing statute, then the solution, they argue, is merely to change the wording of the legislation.

Several witnesses at last week's hearing felt the bureau could have the wider role envisaged in the proposed legislation. It would unduly limit the potential value of the bureau to the nation if its only activities were in the field of metrology.

The committee suggests that the bureau strengthen its links with the academic community by being allowed to make grants and to award fellowships in science and engineering. But $\mathrm{Mr}$ William Carey executive officer of the American Association for the Advancement of Science and until recently chairman of the bureau's board of visitors, warned against this on the grounds that "the granting business these days is bogged down with rules and controls for fiscal accountability" and that "adding another granting agency to the confusion would be regrettable".

How far the committee's recommendations go will depend greatly on how far they agree with the Department of Commerce's own views. Mr Baldridge has already eliminated the position of assistant secretary for science and technology, the post previously occupied by $\mathrm{Dr}$ Jordan Baruch, a principal author of President Carter's domestic policy review on industrial innovation. Upgrading the National Bureau of Standards would be one way of filling the resulting gap.

David Dickson

\section{India in space}

\section{Another orbit}

\section{Lucknow}

India's latest venture into space was the launch of the experimental telecommunications satellite, Apple, aboard the third Ariane test flight last month. Apple is unlikely to prove as successful as the Indian Space Research Organisation must have hoped after one of the two solar panels failed to deploy shortly after launch. But there is a chance that such a small satellite, 616 kilogrammes, can operate satisfactorily with one solar panel for long enough for the bulk of the experimental work to be done.

The Apple programme is only one of the fronts on which India is advancing into space. At the end of May, as part of the first developmental flight of its satellite launch vehicle SLV-3, India placed a 38-kilogramme satellite into a low Earth orbit. That was the second satellite to be put into orbit using the Indian rocket, the first having been launched last July (Nature 286, 324; 1980).

The latest Indian-launched satellite, designated RS-DI, carried a solid-state sensor capable of identifying salient features on the Earth and transmitting data back to the ground stations.

The main objective of the Apple satellite launched on Ariane but built at the Space Application Centre in Ahmedabad, is to gain experience in the operation and management of communications satellites. Yet another satellite, Bhaskara II, is due for launch at the end of the year and is for the development of remote sensing technology.

Experiments planned for Apple include logging the movements of railway wagons and of railway passenger reservations in large cities, the setting up of an interlibrary information system and the development of a "national classroom" for postgraduate engineering students at the five Indian Institutes of Technology. Under the last programme, students at the five centres will be given televised lectures and be able to question the lecturers directly.

Zaka Imam

\section{Occupational health \\ US industry to pay}

\section{Washington}

In a decision that represents a victory for the US labour movement and a major blow to the Reagan Administration's efforts to reduce the burden of health and safety regulations on private industry, the US Supreme Court has ruled that the Department of Labor's Occupational Safety and Health Administration (OSHA) is not required to carry out rigorous costbenefit analyses of new regulations covering exposure to toxic substances before the rules are put into effect.

The drive to put occupational safety and environmental regulations on a strictly cost-benefit footing has been central to the new Administration's "regulatory reform"'strategy. In line with this, the head of OSHA, Mr Thorne Auchter, asked the Supreme Court in March to delay a decision on whether regulations introduced by the Carter Administration in 1978 to reduce workers' exposure to cotton dust were invalid since they had not been accompanied by a thorough analysis of the relative costs and benefits.

However, the court has turned a deaf ear to the agency's request. In a move that will now require both OSHA and the White House to ask for new legislation from Congress if it wants to pursue the strategy, the court ruled by five votes to three, with one abstention, that there is nothing in the law to require such analysis. Rather it has accepted the interpretation of OSHA officials under the previous administration, that the mandate requires the agency to do all it can to reduce health hazards to workers, short of bankrupting the industry concerned.

The new cotton dust regulations, which are already being implemented by most large textile manufacturers, are aimed at 
lowering the incidence of byssinosis (brown lung disease) among the nation's 800,000 textile workers. In 1978 OSHA issued regulations requiring the permissible level of cotton dust to which workers could be exposed to be reduced from 1,000 to 200 microgrammes per cubic metre of air.

Even at the time the ruling was highly controversial. Whereas OSHA officials estimated that the cost of compliance to industry would be about $\$ 650$ million, industry itself put the figure at $\$ 2,700$ million.

The Supreme Court's decision is the final step in a legal challenge launched by the American Textile Manufacturers Association, asking that the rules be disregarded because the agency had not demonstrated that the expected benefits outweighed the likely costs of implementation. If the appeal had been sustained, it would have allowed the Administration to proceed relatively unimpeded with its plan to apply strict cost-benefit analysis to various regulations already in effect - for example those covering exposure to arsenic and lead - with a view to reducing their severity.

This strategy will have to be reassessed, now that the Supreme Court, in a ruling by Justice William J. Brennan, has concluded that OSHA is not required to carry out such an analysis, but merely to determine that its regulations are technically and economically feasible.

Although professing to welcome the justices' verdict, since it formally supports the government's position, OSHA officials also acknowledge that it is a set-back to their attempts to chart a new course for the agency that would be more congenial to private industry. Mr Auchter has already made clear his strong disagreement with the philosophy and policies of his predecessor, Dr Eula Bingham.

Predictably the court's verdict has been warmly welcomed by labour unions representing textile workers, but their jubilation may be premature. Already OSHA officials have revised their approach to new regulations in the light of last July's ruling by the Supreme Court, in rejecting proposed new standards for exposure to benzene (Nature 286, 97; 1980). And following the cotton dust decision, a spokesman for the textile manufacturers said that the companies "continue to believe, as does the Administration, that cost-benefit analysis is an important element in achieving rational and costeffective rule-making",.

But much of the fire has disappeared from the textile industry's complaints, Many companies acknowledge that their calculations of likely costs were based on the conversion of old equipment and that new regulations have led them to buy new machines that have already produced significant gains in profitability. It is a silver lining that few would have expected when the regulations were hailed as a large black cloud over the industry

\section{Dietary vitamin C $\overline{\text { Bigger daily dose? }}$}

Britain's answer to Linus Pauling now argues that the government should raise the recommended daily amount of vitamin $\mathrm{C}$ from $30 \mathrm{mg}$ to $100 \mathrm{mg}$ - enough to saturate body tissues with the vitamin, but nowhere near the "megadose" levels Pauling advocates.

The new British "Mr Vitamin C'" is a mild-mannered Welshman, Dr R. Elwyn Hughes of the University of Wales Institute of Science and Technology. His book on the subject has just been launched by the British Nutrition Foundation, which though supported entirely by the food industry is at pains to provide "balanced" information on nutritional matters. The foundation supports Dr Hughes's recommendation that the government should reassess the criteria by which recommended daily amounts are arrived at, but makes no commitment to the actual level of vitamin $C$ we need. On this $\mathrm{Dr}$ Hughes - officially - stands alone.

We owe the British recommended amounts to a group of conscientious objectors who in 1940 were subjected to zero vitamin $C$ diets. They soon showed the symptoms of scurvy, and their intake of vitamin $C$ was raised slowly until the scurvy disappeared. It disappeared at $10 \mathrm{mg}$ a day; so the government tripled this amount to allow a margin of error.

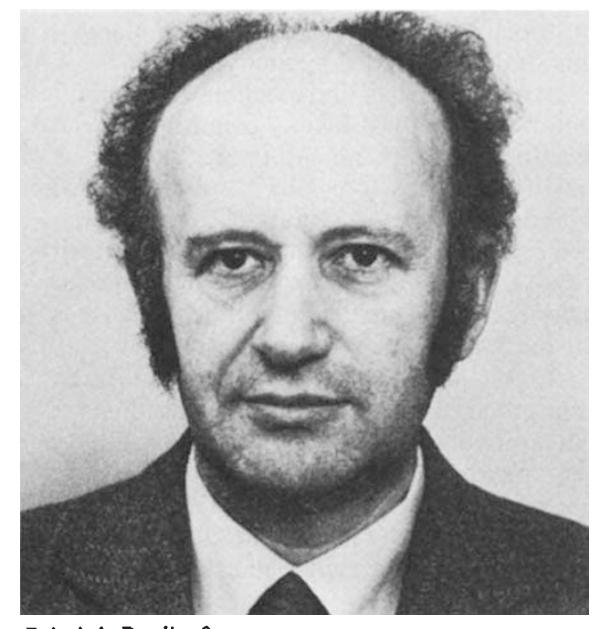

Britain's Pauling?

However, the past decade has seen the discovery of useful functions for vitamin C other than just preventing scurvy, says Dr Hughes, such as involvement in lipid metabolism and atherogenesis; brain metabolism; carnitine metabolism (which relates to muscle fatigue and lack of stamina); resistance to infection; and the detoxification of potentially harmful drugs, including certain tranquillizers. Although such evidence is incomplete it is sufficient to commend tissue saturation levels of the vitamin, he concludes.

According to British dieticians, the average daily intake of vitamin $\mathrm{C}$ in the United Kingdom is $60 \mathrm{mg}$, equivalent to the content of two fresh oranges. But many people take much less. In a survey of old people's homes in South Wales, Dr Hughes discovered average intakes of less than 20 $\mathrm{mg}$, and in some cases less than $10 \mathrm{mg}$.

Dr Hughes does not recommend megadosage, however. Its benefits are unproved, he says. Half of any excess over saturation is swept out in the faeces, and the rest rapidly in the urine; and moreover there is evidence of disadvantage, in particular that toxic metals can be forced across the placental membrane by high vitamin C fluxes.

Robert Walgate

\section{Soviet mineral supplies \\ Digging deeper}

Talk in the West of a "resource war" between the Soviet Union and the United States seems to have prompted a reaction from the Soviet Minister of Geology, Evgenii Kozlovskii. Talking on Radio Moscow, he said that speculation that the Soviet Union would soon become a net importer of mineral ores was mere Western propaganda.

The minister's statements may have been a response to the recent meeting of geologists and Soviet watchers at the Johns Hopkins University (see Nature 11 June, p.444), which concluded that while there was little evidence to support the view of some of President Reagan's more "hawkish" advisers that the Soviet Union was deliberately waging a resource war, there did appear to be production difficulties in the Soviet Union leading to a cutback in mineral exports and the stepping up of imports.

According to Kozlovskii, the Soviet Union can not only meet its own mineral requirements, but also has surpluses for export. Although his assertion that the Soviet Union has the world's largest known deposits of coal, gas, iron, manganese and apatite is probably true, it does not follow that sufficient supplies are available to Soviet industry.

At present, apparently, Soviet geologists are discovering new mineral deposits faster than the mining engineers can extract them. But there is still great emphasis on new methods of surveying for minerais, including satellite surveys and the drilling of deep and "super-deep"' boreholes.

Deep boreholes, in fact, are to play a big part in Soviet geophysical research in the 1980s. The first such hole, on the Kola peninsula, reached a depth of 10,800 metres and a new hole to be drilled in Western Siberia is thought to be of particular significance because of hopes of finding oil deposits in Pre-Jurassic strata at depths of between 5,000 and 7,000 metres. Even deeper drillings are being planned, to depths of greater than 13,000 metres, where high ambient temperatures (up to $350^{\circ} \mathrm{C}$ ) and high pressures will require new drilling techniques and monitoring instruments.

Vera Rich 